\title{
What is the Sympto-Thermal Method? Offering Patients an Alternative Birth Control Option
}

\author{
Farah M Shroff* \\ Department of Family Practice and School of Population and Public Health, University of British Columbia, Canada
}

Submission: August 11, 2017; Published: August 18, 2017

*Corresponding author: Farah M Shroff, Department of Family Practice and School of Population and Public Health, University of British Columbia, Canada, Tel: 60468232696169; Email: farah.shroff@ubc.ca

Keywords: Fertility awareness; Natural family planning; Sympto-thermal method; Contraception; Birth control

\section{Introduction}

The intrauterine device (IUD) and oral contraceptives are the two most common methods of reversible birth control in the world. Both these methods are associated with side effects, particularly in combination with other medications and tobacco and health complications including mood changes, acne, headaches, breast tenderness, pelvic pain, excessive bleeding, amenorrhea, nausea, weight gain and uncommonly, blood clots. Effective and safe birth control that produces fewer side effects would potentially do less harm to women's health. This paper offers clinicians one such option-- the Sympto-Thermal Method (STM).

STM entails observing cervical mucus, gauging basal body temperature, monitoring cervical os changes and can be $97-$ $99 \%$ effective $[1,2]$ when used correctly by motivated couples. Studies indicate that couples using STM for contraception are able to identify their peak fertility days with a method effectiveness of 99.7\% [3] and 93\% of (sampled) women are able to chart an ovulatory mucus pattern [4]. Moreover, unlike other forms of birth control, this system has virtually no side effects and the financial burden is low. Yet a persistent lack of knowledge of STM (also known as fertility awareness, fertility consciousness, the Billings method, natural family planning and other names) hinders its use. Researchers report that many physicians lack the specific knowledge with which to teach or recommend these methods to their patients [5] despite their general understanding of the technique. Unlike other forms of birth control, STM is not marketed by pharmaceutical companies, partly because minimal profit is made from it; family doctors thus have fewer reminders about STM once they have completed medical training. This paper is thus intended to assist GPs in presenting greater choices to their patients by including information about STM. STM can be utilized to achieve or avert pregnancy. It is better known for assisting conception. This paper focuses on contraceptive applications of this technique.

\section{The need for alternative contraception methods}

Table 1: Comparison of various methods of birth control (non permanent).

\begin{tabular}{|c|c|c|c|c|c|}
\hline & Effectiveness & Side Effects & Cost (US \$) & Accessibility & $\begin{array}{c}\text { Protection Against } \\
\text { STIs }\end{array}$ \\
\hline $\begin{array}{l}\text { Injectables eg } \\
\text { depo provera }\end{array}$ & $97-99.7 \%$ [8] & $\begin{array}{l}\text { Weight gain, bone density loss; } \\
\text { irregular bleeding; acne and } \\
\text { backache, mood swings, headache } \\
\text { [8] }\end{array}$ & $\begin{array}{c}\text { Initial exam:\$35- } \\
\text { 250,Quarterly } \\
\text { injection: } \$ 55-150\end{array}$ & $\begin{array}{l}\text { At clinics by } \\
\text { physicians or other } \\
\text { clinicians }\end{array}$ & $\begin{array}{l}\text { None unless used } \\
\text { with male or female } \\
\text { condom }\end{array}$ \\
\hline IUD & $99 \%$ & $\begin{array}{l}\text { Mood changes, acne, excessive } \\
\text { bleeding, headaches, pelvic pain, } \\
\text { nausea and weight gain [8] }\end{array}$ & $\begin{array}{l}\text { Copper: } \$ 30-80 \\
\text { Progesterone IUD: } \\
\qquad \$ 400\end{array}$ & $\begin{array}{l}\text { At clinics by } \\
\text { physicians or other } \\
\text { clinicians }\end{array}$ & $\begin{array}{l}\text { None unless used } \\
\text { with male or female } \\
\text { condom }\end{array}$ \\
\hline Latex & $\begin{array}{c}\text { Male: } 85 \% \\
\text { Female: } 79 \%[8]\end{array}$ & $\begin{array}{l}\text { Allergic reaction to latex, irritation } \\
\text { of penis or the vagina from } \\
\text { spermicides or lubricants }\end{array}$ & $\begin{array}{l}\text { Male: Ranges from } \\
\$ 0.50 \text { to } \$ 1.00 \text { each }\end{array}$ & $\begin{array}{l}\text { At local chemists, } \\
\text { grocery stores; } \\
\text { over the counter }\end{array}$ & $\begin{array}{l}\text { Most protect against } \\
\text { STIs transmitted } \\
\text { through seminal } \\
\text { fluid and skin to skin } \\
\text { contact[8] }\end{array}$ \\
\hline
\end{tabular}


JOJ Nursing \& Health Care

\begin{tabular}{|c|c|c|c|c|c|}
\hline Nuva ring & $\begin{array}{l}92 \% \text { with typical } \\
\text { use } \\
\sim 99 \% \text { with perfect } \\
\text { use[9] }\end{array}$ & $\begin{array}{l}\text { Headache, vaginitis; nausea, } \\
\text { weight gain; ulcerations and } \\
\text { ecchymosis of vaginal surface [9] }\end{array}$ & $\$ 15-80 /$ month & $\begin{array}{l}\text { Through } \\
\text { prescription by } \\
\text { physician or other } \\
\text { clinicians }\end{array}$ & $\begin{array}{l}\text { None unless used } \\
\text { with male or female } \\
\text { condom }\end{array}$ \\
\hline Spermicides & $\begin{array}{l}71 \% \text { in the first } \\
\text { year of use; } \\
85 \% \text { with perfect } \\
\text { use[8] }\end{array}$ & May irritate skin [8] & $\begin{array}{l}\$ 10-15 \text { for foam bottle } \\
\text { or box of film }\end{array}$ & $\begin{array}{l}\text { At local grocery } \\
\text { stores chemists; } \\
\text { over the counter }\end{array}$ & $\begin{array}{l}\text { None unless used } \\
\text { with male or female } \\
\text { condom }\end{array}$ \\
\hline STM & $\begin{array}{l}97-99 \% \text { with } \\
\text { perfect use [2] } \\
75-99 \% \text { with } \\
\text { regular use }\end{array}$ & None & $\begin{array}{l}\text { Training is free } \\
\text { or minimal; BBT } \\
\text { thermometer costs } \\
\quad \$ 10-30^{2}\end{array}$ & $\begin{array}{l}\text { Where there are } \\
\text { coaches }\end{array}$ & $\begin{array}{l}\text { None unless used } \\
\text { with male or female } \\
\text { condom }\end{array}$ \\
\hline The pill & $\begin{array}{c}92 \% \text { in the first } \\
\text { year of use; } \\
\sim 99 \% \text { with perfect } \\
\text { use }[8,9]\end{array}$ & $\begin{array}{c}\text { Nausea, abdominal pain, weight } \\
\text { changes, metrorrhagia, headache } \\
{[8]}\end{array}$ & $\begin{array}{l}\text { Ranges from } \$ 15 \text { to } \\
\$ 35 \text { per month }\end{array}$ & $\begin{array}{c}\text { Through } \\
\text { prescription } \\
\text { by physician } \\
\text { (except in special } \\
\text { circumstances) }\end{array}$ & $\begin{array}{l}\text { None unless used } \\
\text { with male or female } \\
\text { condom }\end{array}$ \\
\hline
\end{tabular}

${ }^{1}$ Permanent methods of birth control include tubal ligation, castration and so forth.

${ }^{2}$ All prices are approximate and in US Dollars. Prices do not include cost of physician's visit.

As illustrated in (Table 1) popular contraceptive technologies are associated with adverse effects. STM provides a non-invasive, low technology alternative to the pill and IUDs. This method has been practiced by indigenous communities for thousands of years, including Native Australians, Cherokee, Hawaiian and Bantu women in southern and eastern Africa. Today, the World Organization of the Ovulation Method Billings (WOOMB), located in Australia, is the largest organization that promotes this method. The Catholic Church, the Chinese government and other bodies sanction this form of birth control.

STM can be adopted by women everywhere. In the developing world, where pregnancy and child birth are major causes of disability and death, it is imperative to implement population health policies to reduce mortality and morbidity. While contraception use in developing countries has been rising, various factors prevent many women from accessing birth control, such as women's position in society, poor quality of services, perceived and experienced side-effects, and cultural/ religious opposition. Natural family planning techniques such as STM provide women with alternatives that are as effective as other methods, have no side-effects and are in many cases supported by religious groups.

\section{What is the sympto-thermal method?}

Pinpointing the time of ovulation is at the core of this method. Avoiding pregnancy using STM consists of abstaining from intercourse for at least three days preceding ovulation and one day after. The safest phase to engage in unprotected sex is after ovulation has definitely occurred and latex protection during the other phases is encouraged. Of the three techniques of STM--cervical mucus observation, basal body temperature graphing, monitoring cervical os size and texture changes--the observation of mucus is considered the most reliable of these and some women use it exclusively. The other two techniques are essentially supplementing mucus observation.

\section{Effectiveness}

Only three methods of birth control are 100\% effective: total abstinence, male castration (not vasectomy), and removal of both ovaries (not tubal ligation). One of the safest and most effective methods to prevent pregnancy is STM--provided that guidelines are rigorously applied [1-3]. Like other methods of birth control, STM is not applied perfectly by most couples. Imperfect or regular use efficacy rates are 75-99\% [6]. A two year pilot project in the Oxford area taught STM to GPs and concluded that STM was effective and should be offered regularly [7]. Despite the fact that STM is efficient, affordable, $100 \%$ reversible and without side effects, it continues to be an uncommon and unfamiliar method of contraception. This gap is likely due to a number of causes:

A. Most primary care providers are uninformed about the effectiveness of STM and confuse it with the rhythm method $[5,6]$.

B. Culturally, there is an inherent trust in medical science and drugs. Most people are unable to critically analyse information about birth control that comes from media reports and corporate advertising.

C. Contemporary social views lead people to believe that therapies should work instantly.

D. Many people are willing to abdicate responsibility for their bodies to professionals; this method requires selfknowledge and responsibility.

E. Of those who are aware of STM:

a. Some may have difficulty with breaking cultural and religious taboos and encouraging patients to touch the genital area.

b. Some are convinced that STM is too much work. 
c. Some patients do not wish to invest the significant amount of time to become effectively trained.

Upon further examination of the workload entailed in this method it appears that the critics of STM have perhaps overstated this aspect of the technique. It is true that learning the technique requires a considerable time commitment but once women have learned STM the time investment is relatively minimal. Many women keep journals. Jotting mucus observations and temperature readings requires less than two minutes a day. Every woman urinates a few times daily and examining cervical mucus while wiping only requires a few extra seconds. For most women, it is not harder than remembering to take a pill once a day, at the same time each day. Furthermore, when STM is used as a conception aid, it is rarely criticized as a time consuming technique in comparison to in vitro fertilization and other forms of reproductive technologies.

\section{Drawbacks of STM}

A fundamental aspect of STM is clear communication between couples. Generally, men hold more power than their female partners. This results in a lack of direct communication with respect to intimate matters. STM works best for couples in which direct and egalitarian communication patterns exist.

Additionally, health complications such as fevers could interfere with temperature and mucus readings. Conditions such as yeast infections, for example, hinder the effectiveness

Table 2: Advantages and disadvantages of STM. of this method. Moreover, a small minority of women may not exhibit clear-cut mucus/temperature patterns despite diligent observations.

Because STM is a skill that needs to be learned, trained coaches are a fundamental component of this technique. Finding such coaches may be difficult, particularly in rural and remote areas. Furthermore, most coaches are Catholic and accept only married Catholic couples. Unmarried, non-Catholics may be ineligible. Ideally, each woman or couple learns this technique from a skilled coach. The training takes approximately 6 months of attending a few classes and charting at home which is a significant investment of time. People who have low literacy skills might experience problems in charting, although they may devise pictures or other means of documenting their mucus, temperature and cervical os changes.

If it is practised in a heterosexual relationship involving unprotected intercourse, both couples ought to be tested for STIs, especially HIV. This is the same for the Pill, IUD, inject able contraceptives and others. Latex barriers such as condoms and dental dams are effective protection against STIs and ought to be utilized in conjunction with STM for couples who are uncertain about their status vis-à-vis STIs. A high level of trust is required to be assured that no STIs will enter into the relationship. For many women their libido is highest during ovulation. Using condoms during this time is a simple solution. Table 2 encapsulates some of the arguments for and against the implementation of STM.

\section{Advantages}

- $\quad$ Safe-free from side effects

- $\quad 97-99 \%$ effective with perfect use; $75-99 \%$ with typical use

- $\quad$ Teaches women (and their partners) about their bodies, specifically about their reproductive cycles

- $\quad$ Free to learn it; however fertility monitoring test sticks are available OTC as an adjuvant help aid

- Materials required are low cost and easily accessible: basal body thermometer, charts, speculum (optional), fertility monitors (optional)

- $\quad$ Can be immediately stopped when pregnancy is desired and implemented to encourage conception

- Good choice for those whose cultural/religious beliefs oppose other forms of birth control

\section{Disadvantages}

- Cannot begin immediately -need to find a coach and spend a few months learning the method.

- $\quad$ Coaches are not readily available for all couples. Catholic married couples have easier access.

- Not as useful as a birth control technique for those with multiple sexual partners, especially sex trade workers; works best when couples are in a monogamous committed relationship.

- During cervical as observations there is a possibility of infection if device or fingers are unclean.

- Having a partner check cervical as may be easier physically for some women but more difficult emotionally.

- Can be frustrating for sexual partners when abstinence is required; abstinence prior to ovulation (half the cycle) is one reliable way of implementing STM-- «la method dure».

Unless couples communicate clearly and frankly with each other, this technique is not possible. Egalitarian relationships form the basis for use of this technique yet most male-female relationships are unequal. 


\section{In closing}

Clinicians ought to be aware of the full range of birth control options available; they are less likely to offer methods of birth control to their patients if they are unaware of them [1]. This paper described STM, a non-invasive and highly effective method of birth control.

While clinicians do not have the time to teach this method themselves they can refer to experts. In the UK, clinicians can refer patients to Fertility UK and information about STM can be found at around the world there are a few organizations that teach this technique, including Serena, Couple to Couple League, and Northwest Family Services. Some of these organizations are religious in nature, so are less accessible to secular couples. Scaling up STM requires more secular coaches.

No form of impermanent birth control is $100 \%$ effective. STM is as effective as other impermanent methods when used according to instructions. It has no side effects. These two reasons alone make this system of birth control worthy of attention.

STM is a time-honoured, non-invasive, low technology method. Latex protection in conjunction with STM is an effective way to protect against sexually transmitted infections. One of the reasons for STM's underuse is the lack of profit motive. Equipment required for this technique is very affordable for virtually every couple.

For women and couples, learning about STM can be an empowering experience which provides tools for limiting or encouraging birth in a natural, low cost, efficient manner. It does not work for everyone. Neither does the pill, IUDs, injectables or any other method. STM is extremely reliable when used correctly by motivated couples, yet a persistent lack of knowledge hinders more widespread use. Doctors and others who work in the area of sexual and reproductive health are in an excellent position to fill the knowledge gap [8,9].

\section{Acknowledgment}

The author would like to thank research assistant Dr. Sundeep Dhaliwal for his assistance in the literature review, citations, journal searches and creation of the tables for this paper; another research assistant, Dr. Li Hong Chen sat alongside the author during the editing phase.

\section{Referances}

1. Pallone SR, Bergus GR (2009) Fertility awareness-based methods: another option for family planning. J Am Board Fam Med 22(2): 147157.

2. Herrmann FP, Heil J, Gnoth C, Toledo E, Baur S, et al. (2007) The effectiveness of a fertility awareness based method to avoid pregnancy in relation to a couple's sexual behaviour during the fertile time: a prospective longitudinal study. Hum Reprod 22(5): 1310-1319.

3. Herrmann FP, Gnoth C, Baur S, Strowitzki T, Freundll G (2005) Determination of the fertile window: reproductive competence of women--European cycle databases. Gynecol Endocrinol 20(6): 305312.

4. Walsh M, Filippini TN (1998) The billings ovulation method. What are the benefits? Aust Fam Physician 27(12): 1082-1083.

5. Altamirano HFJ, Yáñez AR, Meillón HH (2012) Family planning methods based on fertility awareness. Ginecol Obstet Mex 80(4): 276-284.

6. Gribblea J, Lundgrenb R, Velasquezb C, Anastasic E (2008) Being strategic about contraceptive introduction: the experience of the Standard Days Method. Contracepion 77(3): 147-154.

7. Clubb EM, Pyper CM, Knight J (1991) A pilot study on teaching natural family planning in general practice. Popline, pp.130-132.

8. Rakel D, Rakel (2011) Textbook of Family Medicine, USA.

9. Wieder DR, Pattimakiel L (2010) Examining the efficacy, safety, and patient acceptability of the combined contraceptive vaginal ring (NuvaRing). Int J Womens Health 2: 401-409.

\section{Your next submission with Juniper Publishers will reach you the below assets}

- Quality Editorial service

- Swift Peer Review

- Reprints availability

- E-prints Service

- Manuscript Podcast for convenient understanding

- Global attainment for your research

- Manuscript accessibility in different formats

( Pdf, E-pub, Full Text, Audio)

- Unceasing customer service

Track the below URL for one-step submission

https://juniperpublishers.com/online-submission.php 